\title{
Analisis Sistem Pembelajaran Online; Persiapan Pra Pembelajaran
}

\author{
Safri \\ zrsafri@yahoo.co.id
}

\begin{abstract}
The development of science and technology makes the distance becomes closer, changes in information systems from offline to online also have an impact on education, His dilemma all the information can be obtained, regardless of valuable science even garbage too also exist. Because everyone can enter information into this virtual world.

Teachers/Lecturers/Instructors as a source of knowledge are required to be technologically literate, ready or unprepared they should be able to adapt to online learning because of the times demanding so. In order for learning does not produce the science of teaching abysmal then teachers/lecturers/instructors are required to develop learning instruments before implementing online learning.

So like a science then it takes someone to take knowledge from the teacher is to see the morality of the teacher, how to deliver a good, and shorten the way in seeking knowledge even from online learning.

Keywords: e-learning, teachers, lecturers, instructors
\end{abstract}

\section{PENDAHULUAN}

\subsection{Latar Belakang Masalah}

Berburu ke padang datar, dapat rusa belakang kaki, berguru kepalang ajar, bagai bunga kembang takjadi

Pada masa sekarang ini seringkali kita mendengar orang memberikan jawaban "tanya mbah gugel atau tonton youtube saja", Mbah gugel dan youtube seolah solusi untuk setiap permasalahan, orang yang dahulunya tidak bisa memasak, tidak bisa membuat kue, atau kegiatan bisnis, tahu-tahu sudah bisa dan mahir pula, begitu juga dengan permasalahanpermasalahan lainnya.

Fenomena blogger dan youtuber bermunculan, dan salah satu pewarta pernah menyatakan bahwa pendapatan putra Presiden Indonesia Jokowi,
Kaesang lebih besar dari pada gaji Presiden Jokowi. Berdasarkan perhitungan socialblade.com, estimasi uang yang diperoleh Kaesang dari jejaring video yang dibuatnya pada Mei 2013 telah mencapai $1.1 \mathrm{~K}$ dolar AS - $17.4 \mathrm{~K}$ dolar AS atau mencapai Rp 14 juta sampai Rp 186 juta per bulan

Bloger dan Youtuber bermunculan, sehingga masalah baru muncul, akan ada banyak solusi untuk satu permasalah di dunia maya, untuk mengambil keputusan dari banyak solusi memerlukan pengetahuan lebih, kadangkala yang paling sering dianggap informasi yang berguna adalah tranding topik atau halaman google yang paling depan, sementara halaman depanpun juga bisa disusupi informasi yang tidak akurat, dengan alasan siapa saja boleh posting atau pewarta menggunakan 
aplikasi tertentu untuk bisa tetap ada dihalaman depan. Berita atau solusi yang diberikan bisa saja menyesatkan, disusupi spam, malware atau virus, sehingga tingkat kecerdasan pencari informasi dibutuhkan.

Berkaca dari kasus Habatussuadah yang dikutip dari https://farisna.wordpress.com /2011/06/04/akibat-belajar-tanpa-guru-

otodidak/. Kisah orang-orang yang belajar tanpa guru (otodidak), sehingga mereka salah dalam membaca dalil, dikarenakan ada kesalahan penulisan dalam kitab yang mereka baca atau mereka salah membaca, dan tidak ada guru yang mengoreksinya. Sehingga mereka beramal sesuai dengan apa yang mereka baca. Kisah yang dibawakan Asy Syaikh Shalih Fauzan rahimahulloh, hadits riwayat Muslim: "Jintan hitam adalah obat dari segala penyakit kecuali mati". Kemudian datang orang ini dia baca hadits tersebut, dia baca sendiri tanpa bimbingan guru, ternyata di cetakannya terdapat kesalahan penulisan, Habbatus Sauda' yang artinya Jintan Hitam, dia baca menjadi $A l$ Hayyatus Sauda' yang artinya Ular Hitam, sehingga menjadi "Ular hitam adalah obat dari segala penyakit kecuali mati.". Orang ini ketika membaca hadits, diamalkan ilmunya. Dia pergi menangkap ular hitam kemudian dia makan, matilah dia. "Kebodohannya membunuh dia sendiri."

Kalau dia baca di depan guru pasti akan diluruskan bacaannya, akan dibenarkan oleh guru. Jangankan yang seperti itu, jika terdapat kesalahan harokat saja, akan diluruskan oleh guru. Maka ada metode dan manhaj yang hendaknya ditempuh oleh seorang penuntut ilmu.
Dari kisah Khan Academy yang merupakan organisasi pendidikan nonprofit yang didirikan pada 2006 oleh Salman Khan, lulusan MIT dan Harvard Business School. Dengan misi "menyediakan pendidikan berkualitas tinggi untuk semua orang di mana saja", situs webnya menyediakan koleksi online gratis dari sekitar 3200 kuliah mikro via tutorial video yang tersimpan di Youtube dengan berbagai bidang ilmu

Metode yang Khan Academy buat tersebut tentunya dirancang oleh guru, pembelajaran dilakukan bertahap dengan sistematika yang tersusun dengan mengaju dari pelajaran dasar menuju pelajaran berkelanjutan, dengan mengedepankan UKRK (urgensi, kontinuitas, relevansi, dan keterpakaian. Guru/ Dosen/Instruktur menyusun Silabus pembelajaran agar tidak keluar dari jalur yang telah direncanakan. Tentunya Silabus yang disesuaikan dengan media online, dengan durasi waktu yang perlu disesuaikan juga. Media-media pembelajaran online harus dibuat dengan semenarik mungkin dengan waktu yang pas supaya tidak menimbukan kejenuhan dari warga belajar.

Sehingga Guru/Dosen/Instruktur sesuai bidang keilmuan dituntut bisa menyiasati fenomena ini, Mereka dituntut untuk melek teknologi untuk dapat mensinkronisasikan pembelajaran media online dengan tidak melanggar kaidah-kaidah pembelajaran. Jika pembelajaran dilakukan tanpa kaidah yang semestinya maka ilmu yang diperoleh bisa menyesatkan, Guru dan Dosen bertanggungjawab dunia dan akhirat atas ilmu yang diberikan. 


\subsection{Latar Belakang Masalah}

Ketika Mbah Google atau Youtube tidak bisa memberikan jawaban yang memuaskan atas pertanyaan yang diajukan, bisa atas minimnya referensi atau keyword yang diberikan bersifat general, sehingga jawaban yang munculpun menjadi general, alih-alihnya bisa juga akan masuk ke dalam ruang diskusi komunitas yang membahas masalah yang diajukan. Terkadang orang akan bertanya kepada orang lain dilingkungannya untuk lebih banyak mendapat masukan dan saran, interaksi dengan orang lain akan menghasilkan diskusi yang bermanfaat.

Karena saat ini, tekanan pada guru untuk terlibat dalam penelitian dan menerbitkan publikasi profesional sangat besar. Oleh karena itu, kurangnya waktu untuk berfokus pada kualitas proses pengajaran. (Kateřina Dvoroková dan Lumír Kulhánek, CBU International Conference March 22-24, 2017 Prague, Csez Republic)

Supaya ilmu yang "kepalang ajar" tidak muncul dimedia pembelajaran online, maka yang dapat menjawab pertanyaan dari pencari sumber informasi tersebut secara spesifik tentunya adalah Guru/ Dosen/Instruktur. Dengan media pembelajaran online tersebut mereka dituntut untuk mempersiapkan instrumeninstrumen pembelajaran, jika dahulu dilakukan secara offline maka untuk saat ini instrumen tersebut harus di persiapkan secara matang sebelum upload ke media online tentunya dengan parameter yang terukur dan semarik mungkin.

\subsection{Tujuan Penelitian}

Penelitian ini memiliki tujuan:
a. Mempersiapkan langkah- langkah pembelajaran online
b. Materi pembelajaran online
c. Penilaian pembelajaran online

\section{METODE}

\subsection{Metode Penelitian}

Metode analisis data pada penelitian ini adalah penelitian kualitatif induktif, dimana data dimulai dari fenomena yang ada saat ini dan mengemukakan temuan. Dengan jenis penelitian fenomenologi dimana penelitian mengkhususkan pada fenomena dan realitas yang tampak untuk mengkaji penjelasan di dalamnya, yang bertujuan mencari arti atau makna dari pengalaman yang ada dalam kehidupan.

\subsection{Deskripsi Data}

Untuk dapat menggambarkan data penelitian sehingga lebih mudah dimengerti maka deskripsi data penelitian dijelaskan dalam 3 (tiga) pertanyaan untuk menjelaskan e-learning yaitu; Apa, bagaimana dan mengapa.

Apa, adalah penjelasan dari pokok elearning yang memasukan konten berupa informasi dengan metode pembelajaran, teknik pembelajaran, sehingga membantu warga belajar dalam kegiatan belajar mengajar online.

Bagaimana, adalah dimana e-learning dikomunikasikan melalui media online dalam bentuk kalimat, gambar, video, dan lain-lain dengan upaya menjadikan pembelajaran menarik dan tidak membosankan, komunikasi dilakukan dengan acuan synchronous dan asynchronous. 
Mengapa, adalah bertujuan untuk membantu warga belajar dalam memahami materi pembelajaran sehingga ilmu yang diperoleh dapat bermanfaat dan dipertanggung jawabkan

\subsection{Tinjauan Pustaka}

\section{a. Belajar}

Belajar adalah perubahan yang relatif permanen dalam perilaku atau potensi perilaku sebagai hasil dari pengalaman atau latihan yang diperkuat. Belajar merupakan akibat adanya interaksi antara stimulus dan respon. Seseorang dianggap telah belajar sesuatu jika dia dapat menunjukkan perubahan perilakunya. Menurut teori ini, dalam belajar yang penting adalah input yang berupa stimulus dan output yang berupa respons.

Stimulus adalah apa saja yang diberikan guru kepada pelajar, sedangkan respons berupa reaksi atau tanggapan pelajar terhadap stimulus yang diberikan oleh guru tersebut. Proses yang terjadi antara stimulus dan respon tidak penting untuk diperhatikan karena tidak dapat diamati dan tidak dapat diukur, yang dapat diamati adalah stimulus dan respons. Oleh karena itu, apa yang diberikan oleh guru (stimulus) dan apa yang diterima oleh pelajar (respons) harus dapat diamati dan diukur.

Perubahan akibat belajar dapat terjadi dalam berbagai bentuk perilaku, dari ranah kognitif, afektif, dan/atau psikomotor. Tidak terbatas hanya penambahan pengetahuan saja. Sifat perubahannya relatif permanen, tidak akan kembali kepada keadaan semula. Tidak bisa diterapkan pada perubahan akibat situasi sesaat, seperti perubahan akibat kelelahan, sakit, mabuk, dan sebagainya. Proses perubahan tingkah laku dinyatakan dalam bentuk penguasaan, penggunaan, dan penilaian terhadap sikap dan nilai-nilai pengetahuan yang terdapat dalam berbagai bidang studi atau lebih luas lagi dalam berbagai aspek kehidupan. Perubahannya tidak harus langsung mengikuti pengalaman belajar. Perubahan yang segera terjadi umumnya tidak dalam bentuk perilaku, tetapi terutama hanya dalam potensi seseorang untuk berperilaku. Perubahan terjadi akibat adanya suatu pengalaman, praktik atau latihan. Berbeda dengan perubahan serta-merta akibat refleks atau perilaku yang bersifat naluriah. Perubahan akan lebih mudah terjadi bila disertai adanya penguat, berupa ganjaran yang diterima, hadiah atau hukuman sebagai konsekuensi adanya perubahan perilaku tersebut. Proses perubahan dalam belajar menuju ke arah tujuan yang lebih baik dan bermanfaat bagi dirinya maupun orang lain. perasaan bangga dalam diri karena dapat mengerti dan paham akan apa yang di pelajari

\section{b. Definisi Belajar Online}

E-learning berbeda dengan Distance Education, banyak pembuat kebijakan, ilmuwan dan praktisi di bidang pendidikan 
tinggi menggunakan kedua istilah ini secara bergantian sebagai sinonim. Tetapi faktanya adalah bahwa pendidikan jarak jauh di sebagian besar sistem pendidikan tinggi tidak disampaikan melalui media elektronik baru, dan sebaliknya e-learning di kebanyakan universitas dan perguruan tinggi di seluruh dunia tidak digunakan untuk tujuan pendidikan jarak jauh. Distance education dan e-learning banyak tumpang tindih dalam beberapa kasus, namun sama sekali tidak identik. Kurangnya perbedaan antara e-learning dan distance education menyumbang sebagian besar kesalahpahaman peran TIK dalam pendidikan tinggi, dan untuk kesenjangan yang luas antara retorika dalam literatur yang menggambarkan masa depan menyapu baik ICT pada pendidikan lingkungan dan pelaksanaan aktual mereka (Sarah Guri-Rosenblit, 49: 467493 Springer 2005, DOI 10.1007/s10734-004-0040-0)

Sistem pembelajaran elektronik atau e-pembelajaran (Bahasa Inggris: Electronic learning disingkat E-learning) dapat didefinisikan sebagai sebuah bentuk teknologi informasi yang diterapkan di bidang pendidikan berupa website yang dapat diakses di mana saja. E-learning merupakan dasar dan konsekuensi logis dari perkembangan teknologi informasi dan komunikasi. Dengan e-learning, peserta ajar (learner atau murid) tidak perlu duduk dengan manis di ruang kelas untuk menyimak setiap ucapan dari seorang guru secara langsung. E-learning juga dapat mempersingkat jadwal target waktu pembelajaran, dan tentu saja menghemat biaya yang harus dikeluarkan oleh sebuah program studi atau program pendidikan.

\section{c. Sejarah Perkembangan Pem- belajaran Online}

E-pembelajaran atau pembelajaran elektronik pertama kali diperkenalkan oleh universitas Illinois di Urbana-Champaign dengan menggunakan sistem instruksi berbasis komputer (computer-assisted instruction) dan komputer bernama PLATO. Sejak itu, perkembangan Elearning dari masa ke masa adalah sebagai berikut:

(1) Tahun 1990: Era CBT (Computer-Based Training) di mana mulai bermunculan aplikasi e-learning yang berjalan dalam PC standalone ataupun berbentuk kemasan CD-ROM. Isi materi dalam bentuk tulisan maupun multimedia (Video dan AUDIO) dalam format mov, mpeg-1, atau avi.

(2) Tahun 1994: Seiring dengan diterimanya CBT oleh masyarakat sejak tahun 1994 CBT muncul dalam bentuk paket-paket yang lebih menarik dan diproduksi secara massal.

(3) Tahun 1997: LMS (Learning Management System). Seiring dengan perkembangan teknologi internet, masyarakat di dunia mulai terkoneksi dengan internet. 
Kebutuhan akan informasi yang dapat diperoleh dengan cepat mulai dirasakan sebagai kebutuhan mutlak, dan jarak serta lokasi bukanlah halangan lagi. Dari sinilah muncul LMS. Perkembangan LMS yang makin pesat membuat pemikiran baru untuk mengatasi masalah interoperability antar LMS yang satu dengan lainnya secara standar. Bentuk standar yang muncul misalnya standar yang dikeluarkan oleh Airline Industry CBT Commettee (AICC), IMS, SCORM, IEEE LOM, ARIADNE, dsb.

(4) Tahun 1999 sebagai tahun Aplikasi E-learning berbasis Web. Perkembangan LMS menuju aplikasi e-learning berbasis Web berkembang secara total, baik untuk pembelajar (learner) maupun administrasi belajar mengajarnya. LMS mulai digabungkan dengan situssitus informasi, majalah, dan surat kabar. Isinya juga semakin kaya dengan perpaduan multimedia, video streaming, serta penampilan interaktif dalam berbagai pilihan format data yang lebih standar, dan berukuran kecil.

Slogan yang selalu diangkat dalam penerapan e-learning, yaitu "Content is King, Conversation is Queen". Sudah sepantasnya bagi Penggiat e-learning, untuk selalu berusaha me- nyajikan konten yang bisa diterima dengan baik, bisa diakses dengan mudah, dan bisa diiikuti dengan menyenangkan.

Dalam dunia e-learning, SDM merupakan faktor yang sangat vital dalam implementasi elearning. Mengapa demikian? Karena e-learning muncul justru untuk meningkatkan kualitas SDM, baik itu di perusahaan, instansi, institusi/dunia pendidikan, maupun di dalam kehidupan bermasyarakat. Oleh karena itu SDM yang ada perlu dipersiapkan dengan sebaik-baiknya sebelum e-learning dijalankan.

SDM suatu perusahaan/institusi harus mempunyai pola pikir yang menyatakan bahwa elearning menjadi kebutuhan perusahaan/institusi untuk mencapai visi dan misi perusahaan/institusi itu sendiri, sehingga e-learning harus dilakukan. Cara pandang ini tentunya membawa konsekuensi dan menuntut adanya perubahan, diantaranya adalah perubahan budaya kerja di perusahaan/institusi tersebut. Dalam hal ini manajemen SDM sebagai pengelola SDM yang ada tentunya akan membuat kebijakan-kebijakan yang sesuai dengan kebutuhan untuk menjalankan e-learning di perusahaan/institusi tersebut.

\section{E-Learning 2.0}

Istilah e-Learning 2.0 digunakan untuk merujuk kepada cara pandang baru terhadap pembelajaran elektronik yang ter- 
inspirasi oleh munculnya teknologi Web 2.0. Sistem konvensional pembelajaran elektronik biasanya berbasis pada paket pelajaran yang disampaikan kepada siswa dengan menggunakan teknologi Internet (biasanya melalui LMS). Peran siswa dalam pembelajaran terdiri dari pembacaan dan mempersiapkan tugas. Kemudian tugas dievaluasi oleh guru. Sebaliknya, elearning 2.0 memiliki penekanan pada pembelajaran yang bersifat sosial dan penggunaan perangkat lunak sosial (social networking) seperti blog, wiki, podcast dan Second Life. Fenomena ini juga telah disebut sebagai Long Tail learning.

Selain itu juga, E-learning 2.0 erat hubungannya dengan Web 2.0, social networking (Jejaring Sosial) dan Personal Learning Environments (PLE).

\section{d. Synchronous}

\section{dan Asynchronous}

Dalam pembelajara online yang perlu diperhatikan adalah metode untuk berkomunikasi, dan terdapat 2 (dua) metode komunikasi di internet, yaitu; synchronous (contoh: chatting) dan asynchronous (contoh mail, bulletin board, dan lain-lain).

Perbedaan antara synchronous dengan asynchronous yang terutama tergantung dari ada tidaknya jeda antara pertukaran pesan dan fleksibilitas waktu antar pengguna komunikasi tersebut.

\section{Synchronous}

Proses pengirim dan penerima diatur sedemikian rupa sehingga memiliki pengaturan yang sama, sehingga dapat diterima dan dikirim dengan baik. umumnya pengaturan ini didasarkan pada waktu dalam mengirimkan sinyal, dengan kata lain synchronous adalah sistem operasi untuk kejadian yang terjadi pada waktu bersamaan, berkelanjutan dan dapat diprediksi.

\section{Asynchronous}

Proses komunikasi data yang tidak tergantung dengan waktu yang tetap. Asynchronous merupakan operasi yang tidak bergantung waktu. Asynchronous sering disebut juga sebagai Asynchronous Transfer Mode (ATM). Mode ini paling sering digunakan dalam mengirimkan dan menerima data antar 2 alat. Pada mode ini berarti clock yang digunakan oleh kedua alat tidak bekerja selaras satu dengan yang lainnya. dengan demikian data harus berisikan informasi tambahan yang mengijinkan kedua data kapan menyetujui kapan pengiriman dilakukan.

\section{e. Keuntungan dan kerugian be- lajar Online}

Seperti Sebagaimana yang disebutkan di atas, e-learning telah mempersingkat waktu pembelajaran dan membuat biaya studi lebih ekonomis. E-learning mem-permudah interaksi antara peserta didik dengan bahan/ materi, peserta didik dengan dosen/guru/instruktur maupun sesama peserta didik. Peserta 
didik dapat saling berbagi informasi dan dapat mengakses bahan-bahan belajar setiap saat dan berulang-ulang, dengan kondisi yang demikian itu peserta didik dapat lebih memantapkan penguasaannya terhadap materi pembelajaran.

Dalam e-learning, faktor kehadiran guru atau pengajar otomatis menjadi berkurang atau bahkan tidak ada. Hal ini disebabkan karena yang mengambil peran guru adalah komputer dan panduan-panduan elektronik yang dirancang oleh "contents writer", designer e-learning, dan pemrogram komputer.

Dengan adanya e-learning para guru/dosen/instruktur akan lebih mudah:

1. Melakukan pemutakhiran bahan-bahan belajar yang menjadi tanggung jawabnya sesuai dengan tuntutan perkembangan keilmuan yang mutakhir

2. Mengembangkan diri atau melakukan penelitian guna meningkatkan wawasannya

3. Mengontrol kegiatan belajar peserta didik.

Kehadiran guru sebagai makhluk yang hidup yang dapat berinteraksi secara langsung dengan para murid telah menghilang dari ruang-ruang elektronik elearning ini. Inilah yang menjadi ciri khas dari kekurangan elearning yang tidak bagus. Sebagaimana asal kata dari elearning yang terdiri dari "e" (elektronik) dan "learning" (belajar).

\section{f. Distance education and e- learning}

Sistem pendidikan tinggi di seluruh dunia ditantang saat ini oleh teknologi informasi dan komunikasi baru (TIK). Teknologi ini memiliki dampak besar pada tren ekonomi, manajemen korporat dan globalisasi dunia, dan memiliki potensi yang luar biasa untuk membentuk kembali sifat lingkungan studi di manapun, baik dari institusi pengajaran konvensional maupun jarak jauh. Banyak yang terkait dengan ICT sebagai generasi baru pendidikan jarak jauh (Bates 1999, 2001; Garrison 1993, 1999; Niper 1989; Peters 2001). Sudah di tahun 1989 Soren Niper (1989) dalam analisis klasiknya mengidentifikasi tiga generasi pendidikan jarak jauh: yang pertama adalah pengajaran korespondensi; Yang kedua adalah pengajaran multi media - mengintegrasikan penggunaan cetak dengan siaran media, kaset dan beberapa komputer; dan generasi ketiga diidentifikasikan dengan teknologi komunikasi interaktif yang baru.

Banyak pembuat kebijakan, ilmuwan dan praktisi di bidang pendidikan tinggi menggunakan istilah "pendidikan jarak jauh" dan "e-learning" secara bergantian sebagai sinonim, yang menekankan terus-menerus mengaburkan batas antara pendidikan konvensional dan jarak 
jauh (AFT 2000, 2001; Arnold 1999; Evans dan Nation 2000; Ryan 2002; Selinger dan Pearson 1999; Twigg 2001).

Sebuah laporan komprehensif yang dikeluarkan oleh The Pew Learning and Technology Programme di Amerika Serikat menyatakan dengan jelas bahwa: Istilah "distance learning", "distance education", "distributed learning" dan "online learning" digunakan lebih atau kurang. Bergantian (Twigg 2001, hal 4). Beberapa ilmuwan bahkan mengklaim bahwa teknologi baru ini menantang keberadaan universitas berbasis kampus. Arnold (1999), misalnya, berpendapat bahwa teknologi informasi baru menciptakan lingkungan belajar ilmiah yang sesuai dalam masyarakat, bahwa distance education akan menggantikan studi tatap muka di masa depan. Henk van de Molen dalam kata pengantar buku Virtual University - Educational Environments of the Future, yang memberikan gambaran umum tentang implementasi TIK di universitas-universitas Eropa, "Dalam masyarakat online, tidak dapat dipungkiri bahwa universitas harus berurusan dengan teknologi informasi dan komunikasi (TIK), tidak hanya untuk penelitian tetapi juga untuk pendidikan. Beberapa bahkan berpikir menyatakan bahwa universitas sebagai institusi pendidikan akan benar-benar virtual. (van der Molen 2001, hal vii).
Namun, pendidikan jarak jauh di sebagian besar sistem pendidikan tinggi tidak disampaikan melalui media elektronik baru, dan sebaliknya: e-learning di kebanyakan universitas dan perguruan tinggi di seluruh dunia tidak digunakan untuk tujuan pendidikan jarak jauh (Bates 2001; Collis dan Moonen 2001; Guri-Rosenblit 2001a, b, 2002; Harley et al 2002. 2002 Somekh dan Davis 1997; van der Wende 2002). 'Pendidikan jarak jauh' dan 'e-learning' banyak tumpang tindih dalam beberapa kasus, namun sama sekali tidak identik. Menurut sebuah survei barubaru ini di Amerika Serikat, misalnya, lebih dari $85 \%$ siswa di institusi pasca sekolah menggunakan berbagai bentuk elearning

\section{ASPEK PENTING DALAM PEM- BELAJARAN ONLINE}

\subsection{Langkah-langkah Persiapan}

Guru/Dosen/Instruktur sebagai mana kelas offline mempersiapkan, mulai dari Silabus, RPP, Sumber Pembelajaran, Penilaian, dan durasi pembelajaran.

a. Silabus untuk pembelajaran Online

Silabus yang merupakan garis besar pembelajaran dirancang layaknya standar Silabus offline, yang menyatakan level kompetensi dari materi yang akan diajarkan online, dengan berisikan judul materi pembelajaran, deskripsi pembelajatan, audiensi, kompetensi inti, indikator, durasi waktu, syarat mengukuti pelajaran online, dan instrumen penilaian. 
Supaya silabus tetap berada pada koridor pengembangan kurikulum maka, perlu memperhatikan prinsip-prinsip pengembangan silabus, yang meliputi;
1). Ilmiah

2). Relevan

3). Sistematis

4). Konsisten.

5). Memadai

6). Aktual dan Kontekstual.

7). Fleksibel

8). Menyeluruh

\section{SILABUS PEMBELAJARAN}

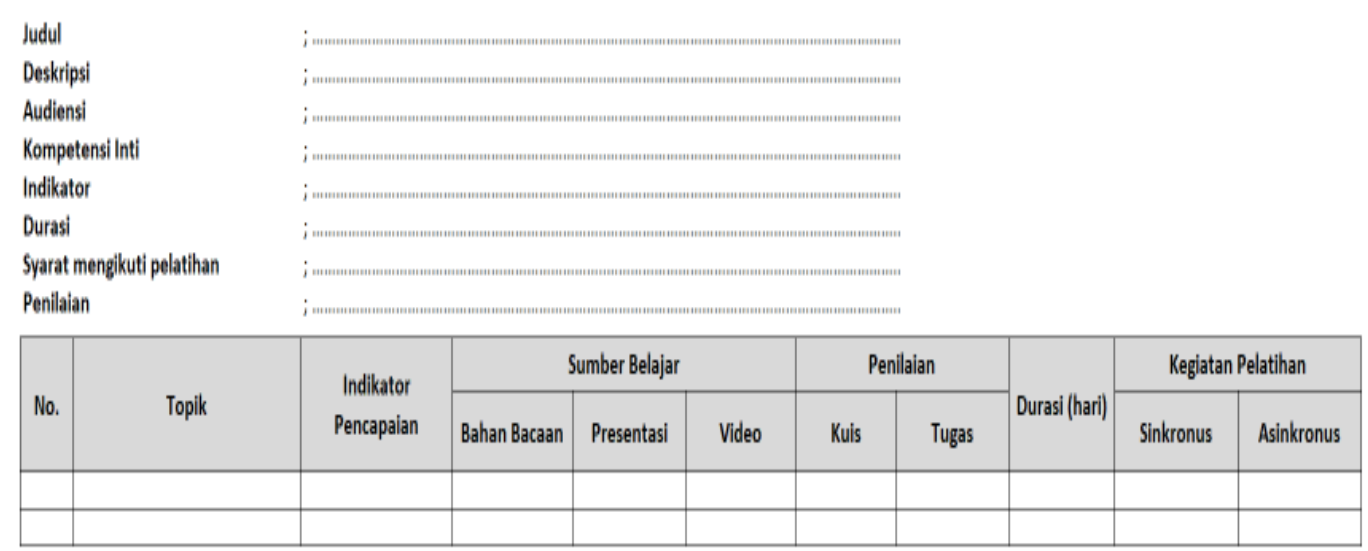

Gambar 3.1. Template silabus online Seamolec (data diolah penulis)

Selanjutnya dari poin-poin tersebut dijabarkan lagi menjadi lebih terperinci melalui topiktopik yang akan dibahas pada kelas online, dengan durasi waktu yang ditentukan, maka topik-topik tersebut lebih baik menyatakan Urgensi, Kontunuitas, relevansi, dan keterpakaian bagi warga belajar.

Indikator pencapaian setiap topik di dukung dengan sumber belajar berupa bahan bacaan yang dapat peserta download, bahan presentasi dengan menggunakan sofware-software pendukung, dan video-video mena- rik sesuai dengan topik pembelajaran.

Untuk menilai hasil dari pembelajaran, guru/doses/instruktur, bisa memberikan kuis online berbatas waktu dengan metode sinkronus, sedangkan pada penilaian penugasan bisa menggunakan metode asinkronous

b. Sumber Pembelajaran Online

1) Bahan Bacaan

Sebaiknya bahan bacaan online disajikan dalam tampilan yang bisa menarik minat membaca, dan disarankan jangan terlampau tebal. 


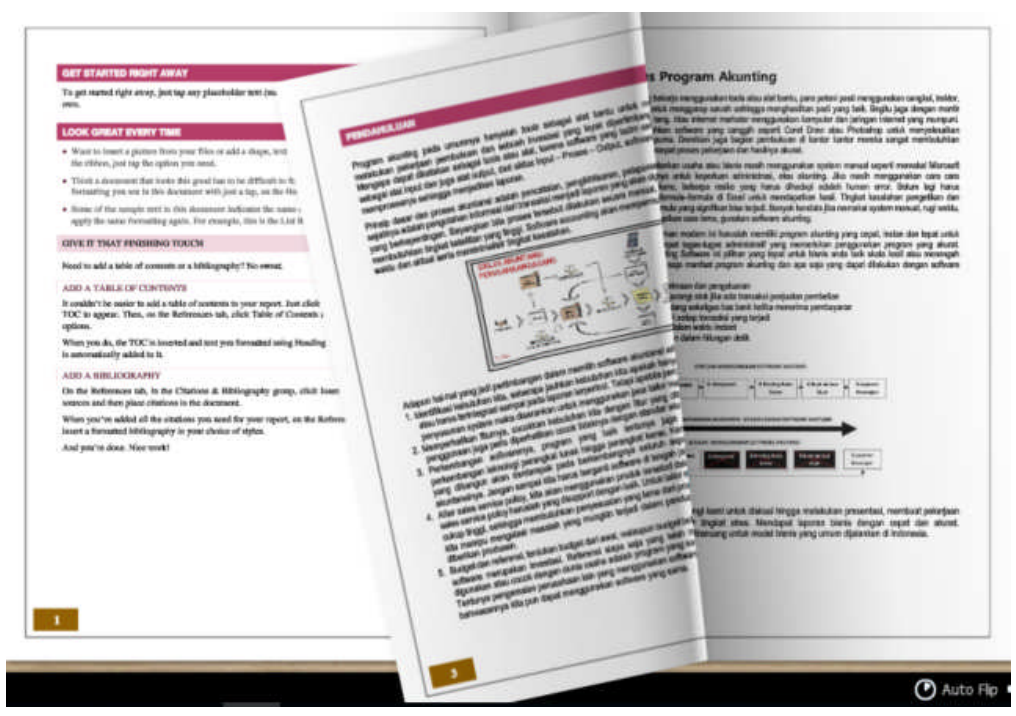

Gambar 3.2. Bahan Bacaan

(data diolah penulis)

2) Presentasi

Sama seperti presentasi di kelas, maka Guru/Dosen/ Instruktur juga diharuskan mempersiapkan materi presentasi, bisa menggunakan microsoft power point, prezi, atau supaya lebih menarik dan tidak membosankan menggunakan media presentasi yang lebih interaktif seperti poowtoon, sparkol, dan lain-lain.

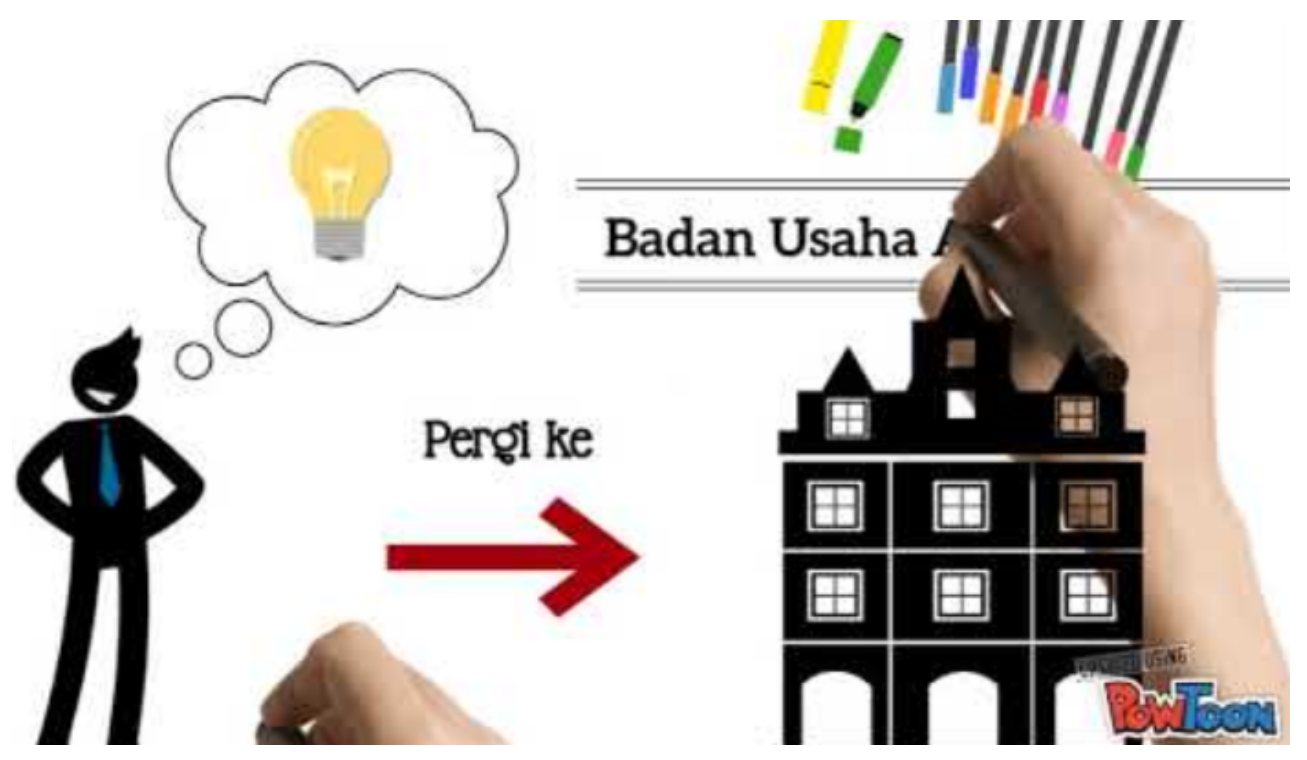

Gambar 3.3. Presentasi Poowtoon

(data https://i.ytimg.com/vi/5N2SjbDU5g8/hqdefault.jpg, diolah penulis) 

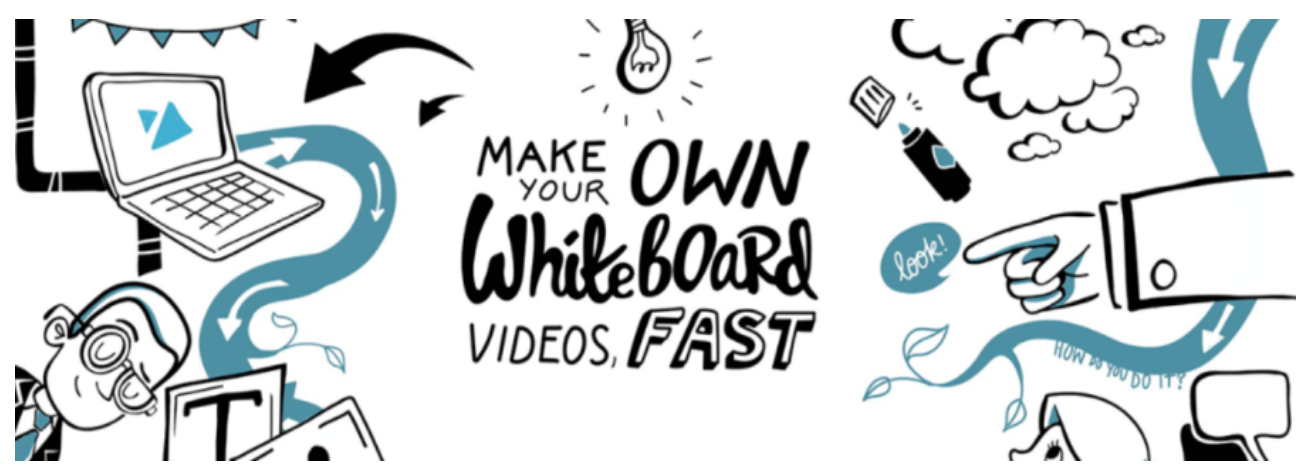

Gambar 3.4. Presentasi Sparkol

(data https://4.bp.blogspot.com, diolah penulis)

3) Video

Ada banyak kelebihan video ketika digunakan sebagai media pembelajaran di antaranya menurut Nugent (2005) dalam Smaldino dkk. (2008: 310), video merupakan media yang cocok untuk pelbagai pembelajaran, seperti kelas, kelompok kecil, bahkan satu siswa seorang diri sekalipun.

Lebih dari itu, manfaat dan karakteristik lain dari media video atau film dalam meningkatkan efektifitas dan efesiensi proses pembelajaran, di antaranya adalah:

a) Mengatasi jarak dan waktu resolusi konflik dan hubungan antar sesama,

b) Mampu

menggambarkan peristiwa-peristiwa masa lalu secara realistis dalam waktu yang singkat.

c) Dapat membawa siswa berpetualang dari, negara satu ke negara lain- nya, dan dari masa yang satu ke masa yang lain.

d) Dapat diulang-ulang bila perlu untuk menambah kejelasan

e) Pesan yang disampaikannya cepat dan mudah diingat

f) Megembangkan pikiran dan pendapat para siswa

g) Mengembangkan imajinasi

h) Memperjelas hal-hal abstrak dengan penjelasan realistik

i) Sebagai media dokumentasi realitas sosial

j) Dapat bertukar pendapat berdasarkan pengalaman masing-masing untuk mendiskusikan sebuah issu dengan efektif

k) Lebih nyata dalam menggambarkan visualisasi konsep

1) Proses operasi gerakan percontohan dapat di perlihatkan lebih efektif.

m) Memungkinkan mengamati peristiwa yang 
membahayakan ketika dilihat secara langsung.

n) Dapat membawa peristiwa bersejarah dalam kehidupan.

o) Dapat melihat sebuah performansi secara terus menerus.

p) Sangat berguna dalam membentuk perilaku individu dan perilaku sosial.

q) Meningkatkan apresiasi yang mendalam terhadap kebudayaan lain.

Video sebagai media visual juga memiliki kelemahan, antara lain;

a) Tidak cocok untuk topik di mana detail pembelajarannya adalah konsep materi yang tidak bergerak, missal- nya peta, diagram, chart, dll.

b) Memerlukan peralatan khusus dalam penyajiannya untuk menampilkan gambar dari sebuah video di butuhkan alat pendukung lainnya

c) Memerlukan tenaga listrik

d) Memerlukan keterampilan khusus dan kerja tim dalam Pembuatannya

e) khusus siaran langsung siaran interaktif, sulit dibuat interaktif

Fenomena Youtuber menuntut Guru/Dosen/Instruktur untuk mengembangkan pembelajaran dalam bentuk video, videopun harus dirancang seinteraktif mungkin, dengan durasi

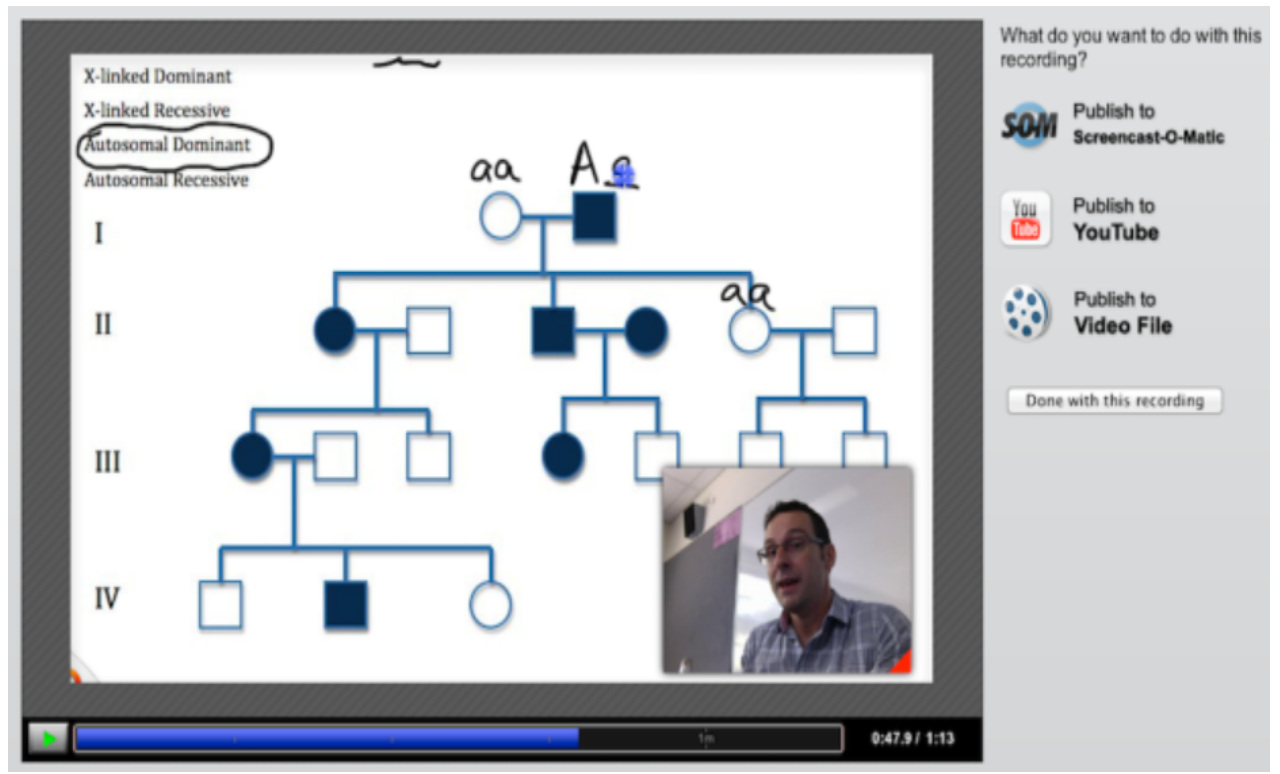

Gambar 3.5. Video Screencast O-Matic

(https://andrewdouch.files.wordpress.com, diolah penulis) 


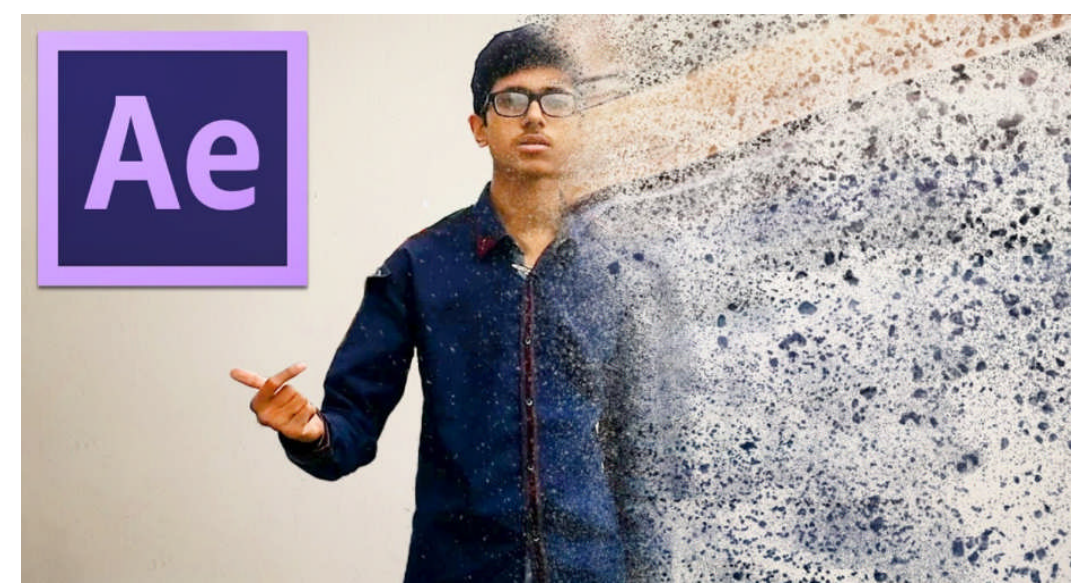

Gambar 3.6. Video dengan After Effects

(https://i.ytimg.com, diolah penulis)

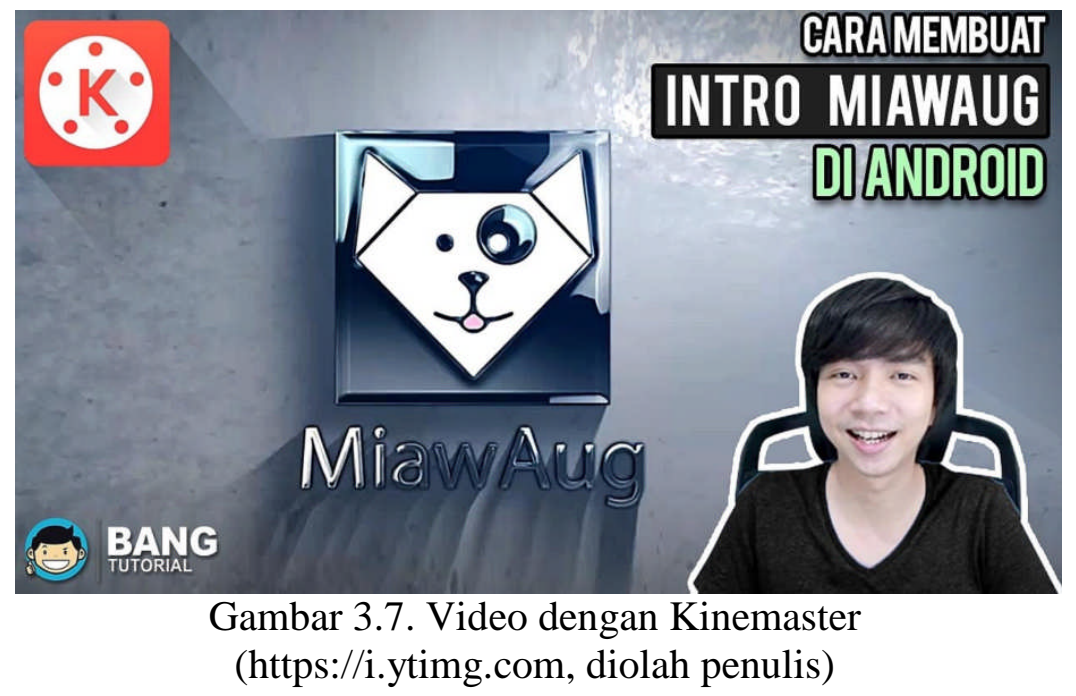

subtitle sangat berpengaruh terhadap menarik tidaknya suatu video, Guru/Dosen/ Instruktur harus menyesuaikan dengan audiensi yang akan melaksanakan pembelajaran online, Selain itu, durasi video pun juga berpengaruh. Berdasarkan laporan dari Kinetic Social dimana orang-orang lebih betah menonton video antara 30 detik sampai 2 menit. c. Penilaian

1) Quis

Quis merupakan instrumen penilaian atas kemajuan dari proses balajar, Quiz online yang interaktif perlu disusun oleh Guru/Dosen/Instruktur untuk mengukur efektifitas pembelajar yang dilakukan pada waktu akhir suatu topik pembahasan. 


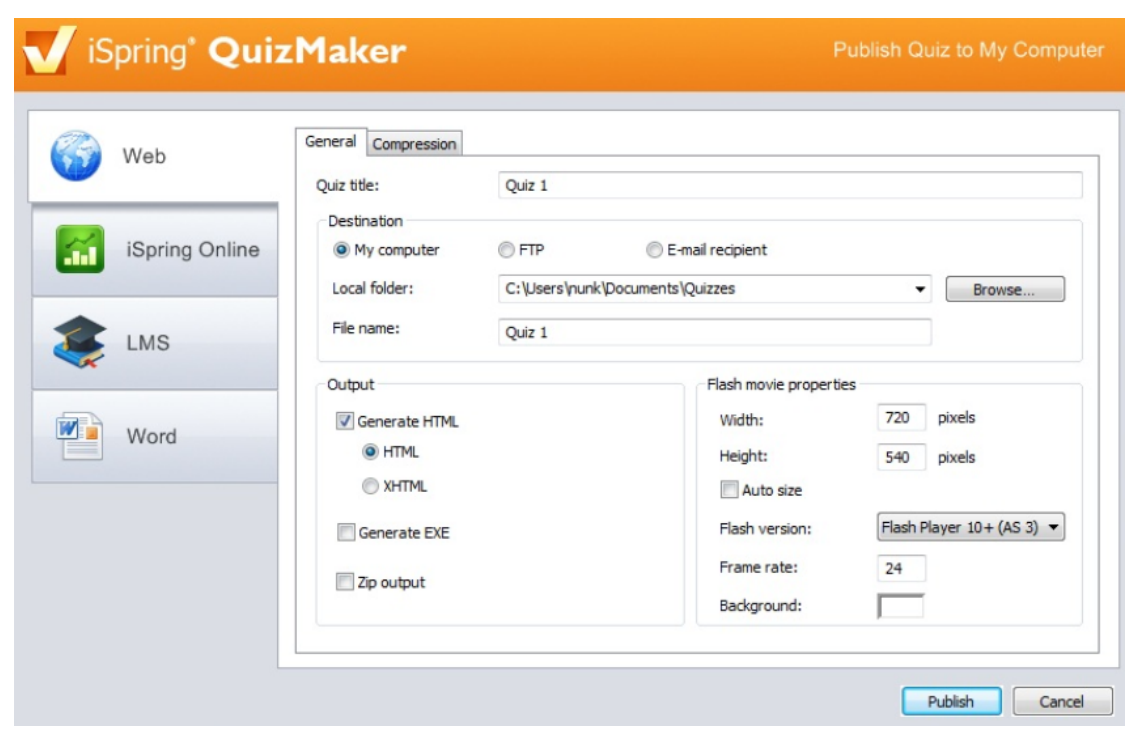

Gambar 3.8. ispring QuizMaker

(https://www.learnupon.com, diolah penulis)

2) Tugas Mandiri.

Tugas mandiri adalah tugas yang diberikan Guru/Dosen/ Instruktur untuk menyelesaikan dalam kurun waktu tertentu dilengkapi dengan kontrak belajar dan waktu penyelesaian disepakati antara

Guru/Dosen/Instruktur dan siswa, tugas mandiri juga akan dievaluasi dalam proses mengerjakannya oleh siswa (http://indosuara.com), Dalam waktu yang telah disapakai tersebut, tugas mandiri dikumpulkan melalui media pembelajaran online.

\section{d. Durasi Waktu}

Sama seperti pembelajaran offline, pembelajaran online juga diharuskan menerapkan satuan durasi untuk menetapkan beban studi siswa. Beban studi yang harus diselesaikan dalam satu program studi diukur dengan satuan kredit semester (sks) contohnya. Setiap mata pembelajarn diberi bobot sks. Satu semester adalah satuan waktu kegiatan belajar.

Dalam sistem pendidikan online, mahasiswa juga harus mengalokasikan waktu yang sama dengan mahasiswa tatap muka. Hanya saja kegiatan belajarnya lebih banyak dilakukan secara mandiri (belajar sendiri, belajar berkelompok, atau tutorial).

\section{KESIMPULAN DAN SARAN}

4.1. Simpulan

Dari pembahasan tentang belajar online maka dapat disimpulkan;

1. Sebelum melaksanakan pembelajaran online Guru/Dosen/Instruktur dituntut untuk mempersiapkan Silabus, Rancangan Pelaksanaan Pembelajar, Sumber-sumber pembelajaran online.

2. Hal yang perlu diperhatikan dalam belajar online adalah bagaiman menciptakan solusi belajar formal 
dan nonformal, menyediakan akses pembelajaran baik itu konten ataupun manusia, mendukung sekelompok orang atau grup untuk belajar bersama, membawa pembelajaran kepada pelajar bukan pelajar ke pembelajaran, dan untuk mengevaluasihasil pembelajaran Guru/Dosen/ Instruktur menggunakan instrumen online bisa berupa quiz online dan tugas mandiri online

3. Sumber-sumber belajar haruslah dikemas dalam sajian yang sangat menarik mungkin sehingga proses trasnformasi ilmu tidak membosankan dan warga belajar dapat menarik manfaat dari pembelajarannya.

\subsection{Saran}

Sama seperti fenomena belanja online, belajar onlinepun sangat cepat sekali perkembangan, sadar atau tidak sadar anak-anak kita sendiri dirumahpun tiap hari sudah dijejali dengan ilmu yang mereka cari sendiri di internet, mereka butuh bimbingan, butuh guru/dosen/ instruktur untuk meluruskan "bacaannya", alangkah sangat disayangkan ilmu yang mereka peroleh tanpa mengikuti kaidah pembelajaran, dalam artian tanpa sistematika perkembangan ilmu dan pengetahuan. Oleh karena itu Guru/ Dosen/Instruktur diharapkan untuk mempersiapkan diri sebelum melaksanakan pembelajaran online dengan semua instrumen yang dapat dilaksanakan layaknya pembelajaran offline. Karena diantara faedah seorang mengambil ilmu dari guru adalah akan melihat akhlaq dari guru dan bagaimana cara penyampaian yang baik dan memperingkas jalan dalam mencari ilmu,

\section{DAFTAR PUSTAKA}

Empy Effendi, SE., MBA, Hartono Zhuang, ST., MBA (2005), elearning Konsep dan Aplikasi, Andi Publiser.

https://upikhardiyanti.wordpress.com/2 010/03/02/contoh-synchronousdan-asynchronous/

https://id.wikipedia.org/wiki/Khan_Aca demy

https://id.wikipedia.org/wiki/Belajar

https://id.wikipedia.org/wiki/Pembelajar an elektronik

http://www.ut.ac.id/sistempembelajaran

https://mooc.seamolec.org/

Kateřina Dvoroková, Lumír Kulhánek," Innovation of The Study Course Using Pearson Higher Education Tools", CBU International Conference on Inovation in Science and Education, March 22-24, 2017, Prague. Csech Republic

Learning Catalytics (2016) Retrieved from

https://www.pearsonhighered.co $\mathrm{m}$ /products-and-services/coursecontent-and-digitalresources/learningapplications/learningcatalytics.html.

Libich, J. (2014). Zabíjí škola touhu po vzdělání? Česká Pozice. Retrieved from http://ceskapozice.lidovky.cz/za biji-skola-touhu-po-vzdelanidzr-/tema.aspx?c= A140808_170423_pozicetema_lube

Rymanova, I., Baryshnikov, N., \& Grishaeva, A. (2015). E-course Based on the LMS Moodle for English Language Teaching: Development and Implementation of Results: 
Development

and Implementation of Results. Procedia - Social and Behavioral Sciences, 206, 236240.

Sarah Guri-Rosenblit, Distance education' and 'e-learning': Not the same thing, Department of Education and Psychology, The Open University of Israel, P.O. Box 39328, Ramat-Aviv, 61392, Israel)

Singh, G., \& Hardaker, G. (2014). Barriers and enablers to adoption and diffusion of e- learning. Education \& Training, 56(2), 105-121.

The Economics of Money, Banking and Financial Markets Global Edition. (2017). Retrieved from http://catalogue.pearsoned.co.uk/ educator/product/TheEconomics -of-Money-Banking-andFinancial-Markets-GlobalEdition/9780273765738.

Who We Are. (2017). Retrieved from https://www.pearson.com/aboutpearson/who-we-are.html 